\title{
トモグラフィ的弾性波探査手法による トンネル地山調査の評価
}

\author{
三木茂 1 吉田幸信 2 井上浩一 3 ・中川浩二4

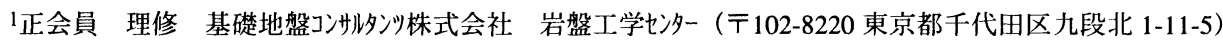 \\ 2日本道路公団 高松技術事務所（下760-0065 香川県高松市朝日町 4-1-3） \\ 3正会員 工修 株式会社ロード・エンジニアリング（テ116-0013 東京都荒川区西日暮里 5-24-7） \\ 4正会員 工博 山口大学教授 工学部 社会建設工学科（テ755-8611 山口県宇部市常盤台）
}

\begin{abstract}
近年，トンネル弾性波探査にトモグラフィ的解析法(トモグラフィ法)が用いられるようになった．トモ グラフィ法を用いた定量的トンネル地山評価を評価するため, 35トンネル44測線についてトモグラフィ法 による解析を行い，従来のはぎとり法に代表される層構造解析(従来法)結果との比較を行った．また，切 羽観察記録における評点に基づき，卜モグラフィ法と従来法の信頼性評価を行った．その結果，筆者らが 対象とした螌囲内において，花崗岩および粘板岩のトンネルでは，トモグラフィ法は従来法に比較して良 好に, 砂岩·頁岩互層では, 従来法と同等に地山状態を推定できていることが明らかになった. トモグラ フィ法が，トンネル弾性波探查において，有効な解析方法であることが実証された。
\end{abstract}

Key Words : seismic velocity, seismic prospecting, tomography, geological evaluation, tunnel

\section{1.はじめに}

山岳トンネルにおける事前調查において，地中の 地山の状態を精度良く捉えるため，その代表的な手 法として弾性波探查(屈折法)が一般的に用いられて きた。 また，この結果を主要な参考資料として支保 区分などが行われている．ところが，弾性波探査を 含めた地質調査の限界, 技術者による判断のばらつ き, 経済的な理由などにより, 十分に地山の状態を 推定することが困難な場合があり, 設計時に想定し た地山の状態と施工時に確認された地山の状態が一 致しない場合が多く見られた"．その結果, トンネ ル施工時において支保変更が頻繁に行われてきた.

支保変更は, 工程管理, 予算管理および安全性の面 からみても好ましいことではなく, 近年の公共事業 費削減やその透明性の要請から考えても好ましいこ とではない。このためにも精度の高い事前地質調查, 弾性波探查の精度向上が求められている.

山岳卜ンネルにおける弾性波屈折法探査の解析手 法としては, 古くから層構造解析が用いられてきた. その代表的な手法がはぎとり法”であり，この手法 が考案された当時は, 今日のようにコンピュータは 存在しておらず, 簡単な計算と図式的解析で層構造 が解析できることに主眼がおかれていた. その後, いくつかの解析手法が研究されてきたが基本的には
層構造を仮定したものであった ${ }^{3)}$.一方，地盤の速 度構造を層構造と仮定せずに解析する手法として開 発された弾性波探査法に弾性波卜モグラフィがある。 弾性波卜モグラフィは，孔間弾性波トモグラフィに 代表されるように, 地盤の精密調査の手法として用 いられているが, 次のような理由により山岳トンネ ルに打ける弾性波探査の解析には用いられてこなか った.

(1)屈折波を考慮できる解析アルゴリズムが実用化 されていなかった。

(2)土木分野では, トモグラフィは孔井間の精査技 術として発展した. また，コストが高かった。

(3)測定チャンネル数や精度において，トモグラフ イ解析に適した測定機器が高価であり一般的 でなかった。

近年においては, 測定機器の高精度化, コンピュ 一タの発達や解析アルゴリズムの改良に伴い，山岳 トンネルにおける弾性波探査の解析においてもトモ グラフィ的に解析する手法が用いられるようになつ てきた4). しかし，多様な地形地質条件について系 統的に適用性を検討した研究はみられない。また， 山岳卜ンネルを対象としたトモグラフィ的解析の結 果について，その結果から想定された地山の状態と 実際の施工時に確認された地山の状態を定量的に比 較検討した事例はみられない。 

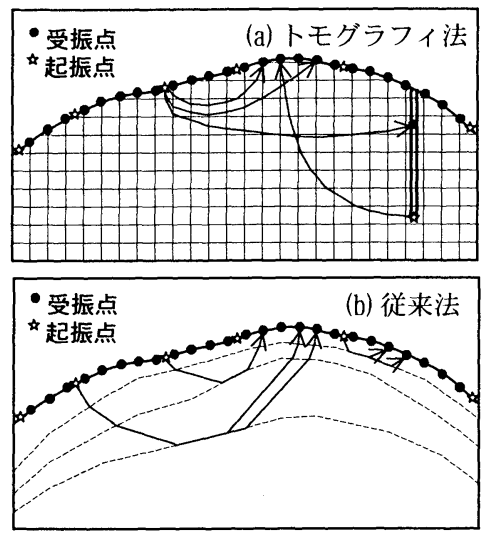

図-1＼cjkstart弾性波探査における地盤のモデル化

一方, 前述のように事前調查·設計と実際の施工 結果が乘離していることが, しばしば指摘されてい る. そこで, 中川ら ${ }^{5}$ は, 事前の弾性波速度による 地山評価と施工実績の切羽観察記録との比較を行い, 弾性波速度による地山の推定度のおおまかな定量的 評価を行っている。一方, 弾性波探査においては, 測定結果からはぎとり法を中心とした地盤の速度構 造を推定する作業において, 解析上の限界から誤差 が大きく現れることが指摘されている゙．この原因 の一つとして, わが国における地山は地質構造が複 雑であり, 地山の速度構造が必ずしも層構造となつ ていないことがあげられる，そこで, 従来から用い られてきた弾性波探查屈折法における層構造解析法 (はぎとり法)に加えて前述のトモグラフィ的解析手 法を用いることで, その精度の向上が期待できる.

本研究では, 実際に掘削された多数のトンネルに ついて, 中川ららの方法に従い, トモグラフィ的解 析手法で得られた弾性波速度に基づき, 切羽の状態 を評点として推定, 実際の切羽観察記録と比較する ことを行った. また, 従来から用いられている層構 造解析と比較を行い，トモグラフィ的解析手法の評 価を行った.これにより，トモグラフィ的解析手法 の定量的地山評価への適用性を検討した. なお，本 研究においては, トモグラフィ的解析手法をトモグ ラフィ法, はぎとり法を中心とした層構造解析法を 従来法と呼ぶことにする。

\section{2.トモグラフィ法の概要と従来法との比較}

トモグラフィ法は図-1 (a) に示すように，地盤を 層構造と仮定せずに格子状に区切り, 各格子のスロ 一ネス (弾性波速度の逆数) を解析する方法である.
解析手法としては，いくつかの手法が提案されてい るが4)・7), 本研究で用いた手法では理論走時の計算 方法として，アイコナールの方程式を差分近似して 走時を計算するVidal ${ }^{8)}$ およびQin et $\mathrm{al}^{9)}$ の方法を, ス ローネスを逆算する方法として同時反復法 (SIRT 法)を用いている。ここで用いた理論走時の計算方 法は, 屈折波の伝播を考慮できる解析手法である.

一方, 高精度屈折法地震波探查 ${ }^{4)}$ もトモグラフィ技 術を応用した解析手法であるが, ホイヘンスの原理 に基づき理論走時を解析している点が, 本研究で用 いた解析手法と大きく異なる.

従来法は図-1 (b) に示すように, 地盤は層構造を 成しており，下位の層ほど弾性波速度が高くなると 仮定し, 各層の弾性波速度と層厚 (深度) を解析する 手法である. 従来法では,

(1)比較的簡単な計算と図式解法で地盤の速度分布 が解析できる.

(2)首構造を示す地盤の速度分布の推定，低速度帯 の検出に優れている.

などの特徵がある. また, 解析結果が比較的単純な 速度層構造として表されることは，速度值から地山 状態を区分することが容易となる実務的利点もある。 一方,

(1)連続的に速度が変化する構造, 複雑に速度が変 化する構造の解析には適切でない.

(2)地形の起伏が少ない地表における起振・受振を 前提とした解析手法である.

(3)解析技術者による任意性が高い. などの欠点がある．また，実際の現場において測定 されたデ一夕を適切に解析するためには経験を要し, 長さ $1 \mathrm{~km}$ 程度のトンネルの場合, 解析に要する時間 は熟練技術者で1週間程度必要とされている.

一方, トモグラフィ法は, 地盤の速度構造を格子 状に分布する速度でモデル化することから，

(1)連続的に速度が変化する構造, 不規則な構造の 解析に有利である.

(2)地表における起・受振に加えて，地中における 起・受振を含めて解析可能である.

(3)波線の通過状況の確認ができる.

(4)コンピュータを利用することで, 短時間で解析 することがきる.

などの長所がある. しかし，地盤を多数の格子でモ デル化することから，

(1)多くの測定走時デー夕を要する.

(2)急激な速度変化のある構造の解析に向かない. などの欠点がある. しかし, 計測機器が発達し多于 ヤンネルで高精度の測定が可能となったこと，ボー 
表-1 切羽観察項目

\begin{tabular}{|c|l|}
\hline 項 目 & \multicolumn{1}{|c|}{ 評価内容 } \\
\hline $\mathrm{A}$ & 切羽の状態 \\
\hline $\mathrm{B}$ & 素掘り面の状態 \\
\hline $\mathrm{C}$ & 圧縮強度 \\
\hline $\mathrm{D}$ & 䖝化変質 \\
\hline $\mathrm{E}$ & 割れ目の頻度 \\
\hline $\mathrm{F}$ & 割れ目の状態 \\
\hline $\mathrm{G}$ & 割れ目の形態 \\
\hline $\mathrm{H}$ & 湧水 \\
\hline $\mathrm{I}$ & 水による劣化 \\
\hline
\end{tabular}

リング孔を利用した走時の測定を取り込めることか ら, 多くの測定デー夕を要することは実質的な欠点 とはならないと考えられる. また，わが国における 地質構造は複雑であり, 地山の速度構造が必ずしも 層構造となっていないことを考えると，トモグラフ イ法は従来法の欠点を補った解析手法であると考え られる。

\section{3. トモグラフィ法による検討方法と対象卜 ンネルの概要}

\section{（1）トモグラフィ法の解析手順}

本研究においては，既に施工が終了しており，従 来法による事前調査結果および切羽観察記録が保存 されているトンネルを検討対象とした. トモグラフ イ法の適用においては，事前調查段階に実施された 従来法弾性波探査の走時図より走時を読み取り，卜 モグラフィ法による再解析を実施した．したがって, 解析に用いた測定走時データは, トモグラフィ法を 前提とした起振点や受振点の配置や精度で実施され たものではない．解析においては，受振点の測点間 隔がトンネル坑口部で $5 \mathrm{~m}$ ，一般部で $5 \mathrm{~m}$ ないし $10 \mathrm{~m}$ であることから，解析に用いる格子は $5 \mathrm{~m}$ とた. また, 解析条件として与える地盤の初期速度は以下 のようにして決定した.すなわち，地盤の初期速度 は一様であると仮定し，対応する岩種において地山 分類 Bから $\mathrm{D}_{1}$ に相当する速度で数ケース解析し, 最もRMS残差が低くなる速度を初期速度とした ${ }^{101}$. 解析の収束判定は, 測定走時と計算走時のRMS残 差が概ね $5 \%$ 以下となること，あるいは，繰り返し 計算を重ねても有意にRMS残差が低下しないこと を基準とした。

トモグラフィ法では，解析結果として地盤の速度 分布と波線の分布が得られる. 解析の特性から，波 線の通過していない格子の解析結果については妥当 性がないので, トンネル全線にわたり波線が通過し
表-2 地山分類表 ${ }^{111}$ に基づき設定した地山の評価

\begin{tabular}{|c|c|c|c|c|c|}
\hline \multirow{2}{*}{$\begin{array}{l}\text { 夕 } \\
1 \\
70\end{array}$} & \multirow{2}{*}{$\begin{array}{l}\text { 弾性 波 速 } \\
\text { 度 Vp } \\
(\mathrm{km} / \mathrm{s})\end{array}$} & \multicolumn{3}{|c|}{ 切羽観察項目：C、D 項目 } & \multirow{2}{*}{$\begin{array}{l}\text { 地山 } \\
\text { 等級 }\end{array}$} \\
\hline & & $\begin{array}{l}\text { 压縮強 } \\
\text { 度: C }\end{array}$ & $\begin{array}{l}\text { 風化変 } \\
\text { 質: D }\end{array}$ & $\begin{array}{l}\text { 切羽強度 } \\
\text { 指数 }(C+D)\end{array}$ & \\
\hline $\mathrm{I}$ & $5.0 \sim$ & \multirow{3}{*}{$1 \sim 2$} & \multirow{3}{*}{$1 \sim 2$} & \multirow{3}{*}{$2 \sim 4$} & \multirow{3}{*}{ A } \\
\hline II & $4.9 \sim$ & & & & \\
\hline III & $3.5 \sim$ & & & & \\
\hline I & $3.8 \sim 5.0$ & \multirow{3}{*}{$2 \sim 3$} & \multirow{3}{*}{2} & \multirow{3}{*}{$4 \sim 5$} & \multirow{3}{*}{ B } \\
\hline II & $3.6 \sim 4.9$ & & & & \\
\hline III & $3.0 \sim 3.5$ & & & & \\
\hline I & $3.3 \sim 3.8$ & \multirow{3}{*}{$2 \sim 3$} & \multirow{3}{*}{$2 \sim 3$} & \multirow{3}{*}{$4 \sim 6$} & \multirow{3}{*}{$\begin{array}{l}\mathrm{C}_{\mathrm{I}} \\
\mathrm{C}_{\pi}\end{array}$} \\
\hline II & $3.1 \sim 3.6$ & & & & \\
\hline III & $2.0 \sim 3.0$ & & & & \\
\hline I & $2.6 \sim 3.3$ & \multirow{3}{*}{3} & \multirow{3}{*}{$3 \sim 4$} & \multirow{3}{*}{$6 \sim 7$} & \multirow{3}{*}{$D_{I}$} \\
\hline II & $2.6 \sim 3.1$ & & & & \\
\hline III & $1.5 \sim 2.0$ & & & & \\
\hline I & $\sim 2.6$ & \multirow{3}{*}{$3 \sim 4$} & \multirow{3}{*}{4} & \multirow{3}{*}{$7 \sim 8$} & $\mathrm{D}_{\mathrm{I}}$ \\
\hline II & $\sim 2.6$ & & & & $\mathrm{E}$ \\
\hline III & $\sim 1.5$ & & & & \\
\hline
\end{tabular}

\begin{tabular}{|c|c|}
\hline タイプ & \multicolumn{1}{|c|}{ 代表的な岩種 } \\
\hline I & 結晶片岩、粘板岩、砂岩·頁岩互層 (中生代) \\
\hline II & 花崗岩、流紋岩質凝灰岩 (中生代) \\
\hline III & 凝灭角䂰岩、泥岩 (新第三紀) \\
\hline
\end{tabular}

たトンネルを検討対象として, 従来法との比較, 切 羽観察記録による検討を行った。一方，従来法によ る結果は, 事前調査で得られた弾性波探査解析結果 である

\section{（2）切羽観察記録による弾性波探査結果の定量的評 価方法}

一般に道路トンネルにおいては, 弾性波速度や地 質状況を参考に $\mathrm{B}, \mathrm{C}_{\mathrm{I}}, \mathrm{C}_{\mathrm{II}}$ などの支保区分が行 われる．事前調査段階において弾性波速度から地山 分類"'に従い決定した支保区分と，実際の施工にお いて採用された支保区分を比較することにより，弾 性波探查結果の妥当性を評価することが考えられる. しかし，実際の施工においては，地山状況に加えて 施工性, 安全性を加味して支保パターンが決定され ている.このため，弾性波探査結果を評価すること において，施工時の支保パターンを用いることは, 必ずしも妥当な方法とは言えない。一方，施工時に 実施される切羽観察記録は，比較的忠実に地山状態 を記録していると考えられる，そこで，中川らうは， 表-1に示すトンネル切羽観察記録 ${ }^{221}$ の記載項目のう ち，C項目とD項目に着目し，表-2に示す弾性波速 度による地山評価表を作成し，弾性波探査結果と切 羽観察記録の関係を示した，そこで，本研究では表 -2に従い，トモグラフィ法あるいは従来法で得られ た速度值からC+Dの評点を推定し，実際の切羽観察 
記録と比較することで，トモグラフィ法の評価を行 うものとする. なお，ここでは， C+Dの評点を切羽 強度指数と呼ぶことにする. 以下, 切羽強度指数に よる検討方法を示す.

トモグラフィ法においては, 切羽強度指数の推定 は, 解析で得られた弾性波速度分布から, トンネル 中心での速度値を拾い出し, 表-2に基づき行う. 従 来法については, 事前調查段階に実施された弾性波 探查の結果である速度構造断面図からトンネル中心 での速度を拾い出し, 切羽強度指数の推定を行う. 実際の切羽観察記録との比較においては, トモグラ フィ法あるいは従来法から推定された切羽強度指数 の範囲が，切羽観察記録の切羽強度指数を含む場合， 両者は一致したと判断し, 切羽観察記録における評 点とのランク差を0とした. 一方, 切羽観察記録の 切羽強度指数が, 弾性波探査から推定された值より 低い場合, 切羽観察記録とのランク差は負の值とし て, その数值は, (切羽観察記録の切羽強度指数) (弾性波探查による切羽強度指数) の絶対値の最小値 とした. この場合, 弾性波探査結果から想定された 地山状態より実際の地山状態は良好であったことに なる. また, 切羽観察記録の切羽強度指数が, 弾性 波探査から推定された值より高い場合は, 切羽観察 記録とのランク差は正の值とした. なお, 切羽観察 記録において, 例えばC項目の評点が 2 3 記載さ れていた場合，その評点は 2.5 と処理した. また, その結果として切羽強度指数が5.5となり, 弾性波 探査から推定された切羽強度指数が6となった場合, ランク差は0とし両者は一致したと判定している.

トモグラフィ法の地山評価への適用性は, 各トン ネルにおいて，解析結果から推定される切羽強度指 数と切羽観察記録における切羽強度指数の一致率に 基づいて評価することができる. すなわち，トモグ ラフィ法における切羽強度指数の一致率が, 従来法 に比較して同等か良好であれば, 地山評価への適用 性があるとみなせる. ここで, 切羽強度指数の一致 率 (以降, 切羽強度指数一致率) は, 各トンネルにお ける検討区間の総切羽観察記録枚数に対して, 弾性 波速度から推定された切羽強度指数と切羽観察記録 における切羽強度指数が一致した枚数の比率と定義 する. また，前述のようにトモグラフィ法では，卜 ンネル深度に波線が通過しない場合がある。このよ うな場合, 従来法と切羽強度指数一致率の比較を行 うことができないので，そのトンネルは検討対象か ら除外した. また, トンネル坑口部において土被り 厚が20m以下の部分についても検討から除外した.

一方, 弾性波探查においては, 局所的に地山が破
砕されていると想定される低速度帯を検出すること も重要な要素である. しかし, 低速度帯については,

(1)従来法では解析技術者の経験や判断による任意 性が強い。

(2)弾性波探査で推定された低速度帯の存在や位置 が，切羽観察記録に明確に表れていない場合 が多く, 観察者の任意性がある.

などの問題点がある. また, トモグラフィ法におい ても, 解析手法の特性から解析結果に低速度帯が表 れにくい特徵があり，低速度帯の評価を行う基準を 設定しにくい状況にある，そこで，今回の検討にお いては, 低速度帯の存在や位置の特定についての評 価は行なわず，低速度帯を含めた全体として評価を 行った.

\section{（3）対象トンネルの概要}

対象としたトンネルは, 表-3 に示す 35 トンネル である．トンネルは全て道路トンネルであり，主に 中国地方, 四国地方, 近畿地方北部に位置するもの である. トンネルの長さは $166 \sim 1582 \mathrm{~m}$, 最大土被 り厚は 20〜 $157 \mathrm{~m}$ であり, トンネルの総延長は $10141 \mathrm{~m}$ である. トモグラフィ法による解析を行っ た測線本数は 44 測線であり, 総測線長は $22675 \mathrm{~m}$ である. また，検討を行った切羽観察記録枚数は 2007 枚である. なお, 表-3 に示したトンネルのう ち, 測線長の項目が 2 段あるいは 3 段となっている のは, 1 トンネルに対して, 測線が 2 あるいは 3 測 線に分けて探查されたことを意味する. また， $\mathrm{A}-3$ および A-4 トンネルについては, 1 測線で両トンネ ルの探査が行われたことを意味している。

対象としたトンネルの地質は, 花崗岩, 中古生代 の粘板岩, 中生代の砂岩·頁岩互層, 結晶片岩, 流 紋岩質凝灰岩, 蛇紋岩である. 花風岩は, 主に広島 県, 山口県に分布するもので, 地質学的には広島型 花崗岩に分類されるものである. 中古生代の粘板岩 は, 京都府, 岡山県, 高知県に分布するもので, 砂 岩やチャート, 輝緑凝灰岩などを挟在する. 中生代 の砂岩·頁岩は愛媛県, 徳島県に分布するもので, 和泉層群に属するものである. 結晶片岩は, 主に山 口県に分布するものと徳島県に分布するものである. 流紋岩質凝灰岩は山口県に分布するもので, 蛇紋岩 は高知県に分布するものである.

また, 表-3におけるタイプは, 表-2に示した岩種 に対応する．検討を行ったトンネルにおいて，花岡 岩 (G-1〜 6) および流紋岩質凝灰岩 (Tf) はタイプ II に 属するが, それ以外も岩種については全てタイプ I となる.なお，今回対象とした流紋岩質凝灰岩は， 
表-3 対象トンネルの概要と切羽強度指数一致率

\begin{tabular}{|c|c|c|c|c|c|c|c|c|}
\hline \multirow[t]{2}{*}{ トンネル名 } & \multirow[t]{2}{*}{ 所在地 } & \multirow[t]{2}{*}{ 地 質 } & \multirow{2}{*}{$\begin{array}{l}\text { 夕 } \\
1 \\
70\end{array}$} & \multirow{2}{*}{$\begin{array}{l}\text { 測 線 長 } \\
\text { (m) }\end{array}$} & \multirow{2}{*}{$\begin{array}{l}\text { 最大土被 } \\
\text { り厚 (m) }\end{array}$} & \multirow{2}{*}{$\begin{array}{l}\text { 波線通過 } \\
\text { 率（\%) }\end{array}$} & \multicolumn{2}{|c|}{$\begin{array}{c}\text { 切羽強度指数一致率 } \\
(\%)\end{array}$} \\
\hline & & & & & & & $\begin{array}{l}\text { トモグラ } \\
\text { フィ法 }\end{array}$ & 従来法 \\
\hline$G-1$ & 山口県 & \multirow[t]{6}{*}{ 花崗岩 } & \multirow[t]{6}{*}{ II } & 880 & 112 & 100 & 81 & 48 \\
\hline$G-2$ & 山口県 & & & 300 & 30 & 100 & 68 & 36 \\
\hline $\mathrm{G}-3$ & 山口県 & & & 250 & 57 & 100 & 39 & 42 \\
\hline $\mathrm{G}-4$ & 岡山県 & & & 880 & 169 & 30 & & 93 \\
\hline$G-5$ & 岡山県 & & & 760 & 125 & 20 & 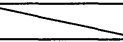 & 68 \\
\hline$G-6$ & 広島県 & & & $\begin{array}{l}750 \\
840\end{array}$ & $\begin{array}{l}100 \\
114\end{array}$ & 40 & & 64 \\
\hline$S-1$ & 岡山県 & \multirow[t]{15}{*}{ 粘板岩 } & \multirow[t]{15}{*}{ I } & 600 & 80 & 100 & 95 & 97 \\
\hline $\mathrm{S}-2$ & 京都府 & & & 720 & 112 & 100 & 87 & 73 \\
\hline$S-3$ & 京都府 & & & 360 & 78 & 100 & 72 & 91 \\
\hline$S-4$ & 高知県 & & & 240 & 48 & 100 & 76 & 11 \\
\hline$S-5$ & 高知県 & & & 310 & 86 & 100 & 98 & 66 \\
\hline$S-6$ & 京都府 & & & $\begin{array}{l}200 \\
210\end{array}$ & 71 & 100 & 34 & 45 \\
\hline$S-7$ & 京都府 & & & $\begin{array}{c}90 \\
400 \\
\end{array}$ & $\begin{array}{c}37 \\
119 \\
\end{array}$ & 100 & 57 & 46 \\
\hline$S-8$ & 岡山県 & & & $\begin{array}{l}300 \\
300\end{array}$ & 90 & 25 & & 84 \\
\hline$S-9$ & 岡山県 & & & $\begin{array}{l}410 \\
510\end{array}$ & 136 & 5 & & 52 \\
\hline $\mathrm{S}-10$ & 高知県 & & & 350 & 49 & 100 & 93 & 0 \\
\hline $\mathrm{S}-11$ & 高知県 & & & 520 & 67 & 100 & 48 & 97 \\
\hline $\mathrm{S}-12$ & 高知県 & & & 660 & 88 & 100 & 70 & 49 \\
\hline $\mathrm{S}-13$ & 高知県 & & & 300 & 67 & 100 & 94 & 29 \\
\hline$S-14$ & 高知県 & & & $\begin{array}{l}640 \\
380\end{array}$ & $\begin{array}{c}149 \\
70\end{array}$ & 60 & & 77 \\
\hline$S-15$ & 高知県 & & & $\begin{array}{l}320 \\
485 \\
\end{array}$ & $\begin{array}{l}82 \\
81 \\
\end{array}$ & 60 & & 81 \\
\hline$A-1$ & 徳島県 & \multirow[t]{8}{*}{ 砂岩頁岩互層 } & \multirow[t]{8}{*}{ I } & 580 & 52 & 100 & 62 & 79 \\
\hline$A-2$ & 徳島県 & & & 205 & 30 & 100 & 7 & 7 \\
\hline$A-3$ & \multirow[t]{2}{*}{ 徳島県 } & & & \multirow[t]{2}{*}{550} & 45 & 100 & 94 & 94 \\
\hline$A-4$ & & & & & 54 & 100 & 97 & 97 \\
\hline$A-5$ & 徳島県 & & & 330 & 30 & 100 & 72 & 74 \\
\hline$A-6$ & 徳島県 & & & 390 & 57 & 100 & 86 & 87 \\
\hline$A-7$ & 徳島県 & & & 575 & 73 & 100 & 52 & 60 \\
\hline$A-8$ & 徳島県 & & & 950 & 68 & 80 & 7 & 99 \\
\hline $\mathrm{Sh}-1$ & 山口県 & \multirow[t]{4}{*}{ 結晶片岩 } & \multirow[t]{4}{*}{ I } & 430 & 49 & 100 & 59 & 44 \\
\hline $\mathrm{Sh}-2$ & 山口県 & & & $\begin{array}{c}910 \\
1150 \\
\end{array}$ & $\begin{array}{l}200 \\
194 \\
\end{array}$ & 80 & & 47 \\
\hline $\mathrm{Sh}-3$ & 山口県 & & & 900 & 157 & 10 & & 44 \\
\hline $\mathrm{Sh}-4$ & 德島県 & & & $\begin{array}{l}900 \\
610 \\
500 \\
\end{array}$ & $\begin{array}{l}147 \\
147 \\
121 \\
\end{array}$ & 70 & & 21 \\
\hline $\mathrm{Sp}$ & 高知県 & 蛇紋岩 & $\mathrm{I}$ & 330 & 60 & 100 & 83 & 9 \\
\hline $\mathrm{Tf}$ & 山口県 & 流紋岩質凝灰岩 & II & 400 & 67 & 100 & 60 & 0 \\
\hline
\end{tabular}

形成年代が中生代と古く, 岩質が結晶質であること からタイプIIに分類した．今回検討したトンネルに おいては, タイプ而に属する地質は含まれていない. なお，岩種区分を代表する名称として，ここで示し た花崗岩, 粘板岩, 砂岩·頁岩を用いるものとする.
前述のようにトモグラフィ法における切羽強度指 数一致率の検討は，波線通過率が $100 \%$ となる測線 で行ったが，表-3に示すように波線通過率が $100 \%$ とならないトンネルは, 測線が2ないし3測線に分割 されている場合が多い(例えば，G-6,Sh-4トンネルな 

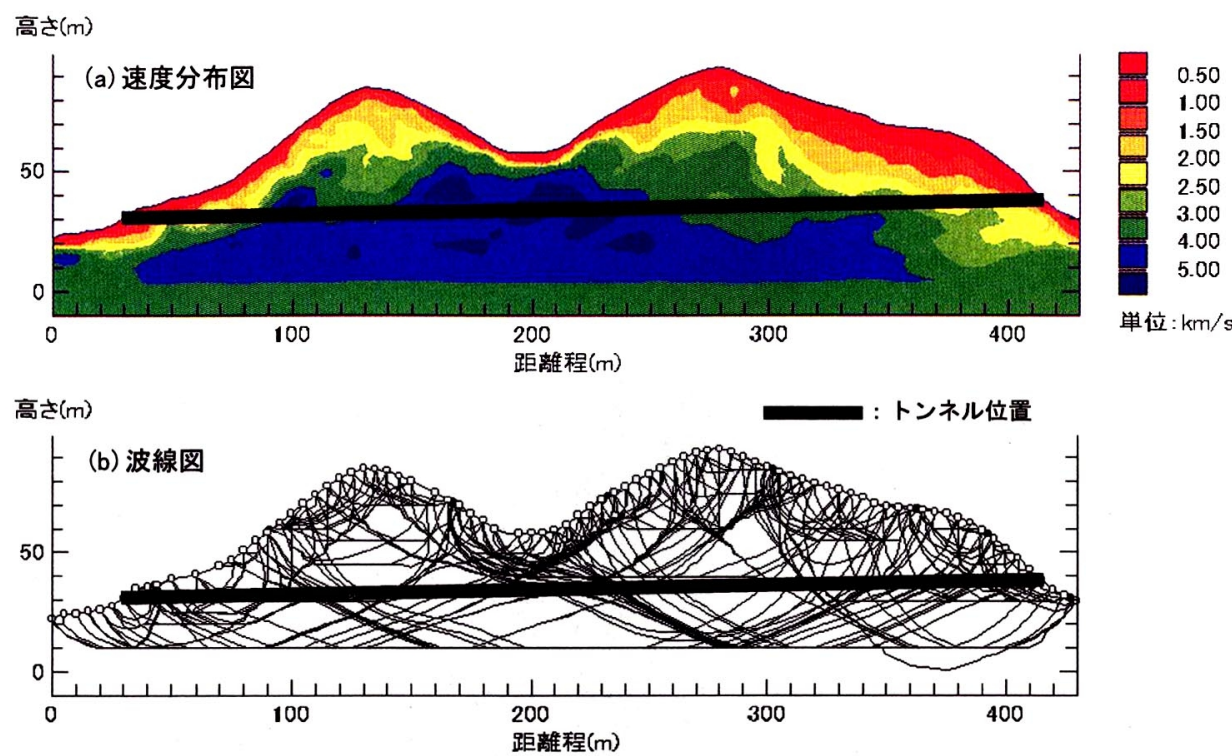

図-2 トモグラフィ法による解析結果(Sh-1 トンネル)

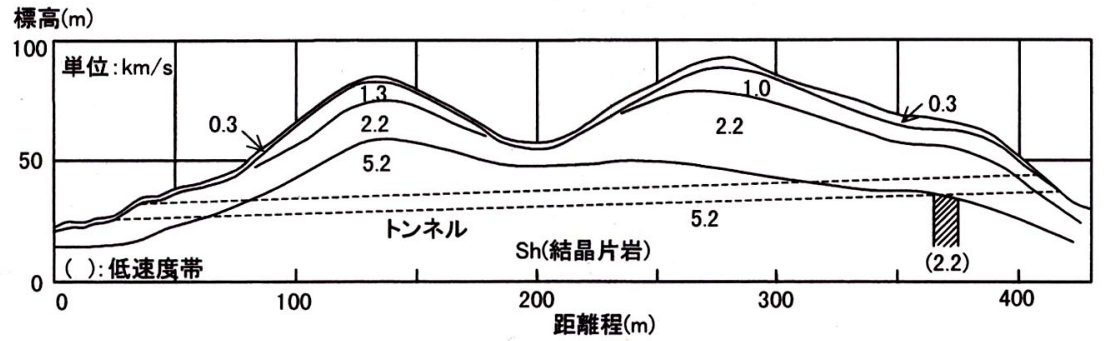

図-3 従来法における速度構造断面図(Sh-1 トンネル)

ど). 複数の測線に分けて探査が行われた9トンネル については, 波線通過率が $100 \%$ となったのは 2 トン ネルにすぎない, 一方, 単一測線で探查が行われた 26トンネルについては，22トンネルで波線通過率が 100\%となっている。このことは, 測線を分割して 探査を行うときの測線長や起振点配置などに関する 問題点を示唆していると考えられる.

\section{4.トモグラフィ法を用いた弾性波探查の検 討}

\section{（1）トモグラフィ法解析結果の概要}

トモグラフィ法の解析には, 筆者の一人(三木)が 開発したプログラムを用いた ${ }^{13)}$. 各トンネルのトモ グラフィ法による解析結果の概要は, 表-3に示した とおりである. 解析に用いた走時データ数は 57 882 であり, 測線延長 $100 \mathrm{~m}$ 換算における走時データ 数は, 平均78であった. また, 収束と判定したとき
のRMS残差は2.9〜17.9\%であり，平均6.4\%であった．

トモグラフィ法における解析結果例 (Sh-1トンネ ル)を図一に示す．また，同じトンネルにおける従 来法の解析結果を図-3に示す，両手法の速度断面図 を比較すると，従来法においては，速度分布は層区 分された速度層断面図としてあらわされるのに対し て, トモグラフィ法では連続的変化する速度分布図 で表されている．両者を比較すると，弾性波速度 $1 \mathrm{~km} / \mathrm{s}$ 前後の表層については, 両手法で速度分布に 大きな差はみられない。しかし，トンネル計画断面 付近では, 従来法では弾性波速度 $5.2 \mathrm{~km} / \mathrm{s}$ のほぼ一 様な速度層と解析されているのに対して，トモグラ フィ法では速度の変化が見られ， $5 \mathrm{~km} / \mathrm{s}$ 以下の速度 なる部分が多い．図-2(b)に示すように，波線がト ンネル計画面を通過していることから，トモグラフ イ法で解析された速度値は, 測定走時を反映したも と考えられる.また，図-2(b)で波線が通過してい ない部分のセルの速度值は, 初期設定速度のままで あり, 波線は速度分布図における解析の妥当性を判 


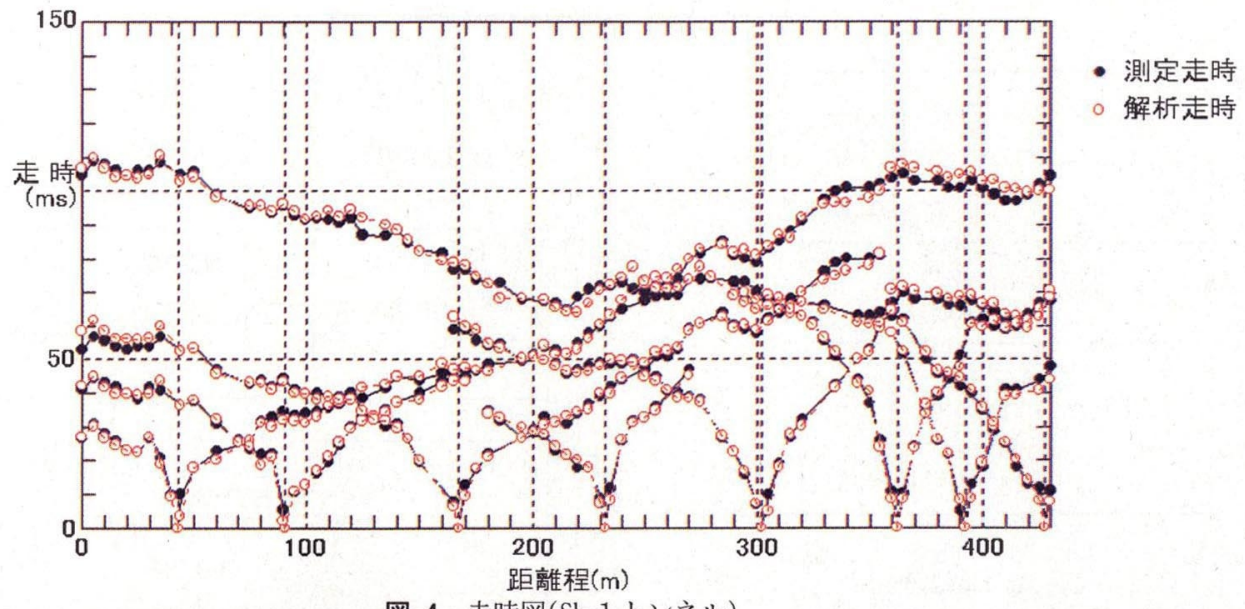

図-4 走時図(Sh-1 トンネル)

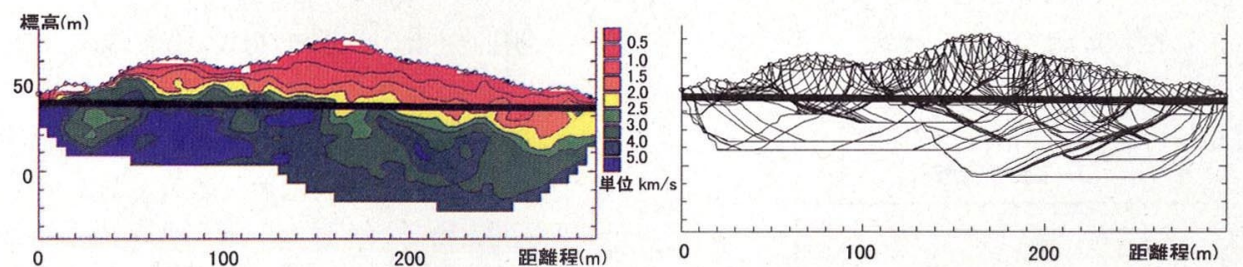

G-2トンネル

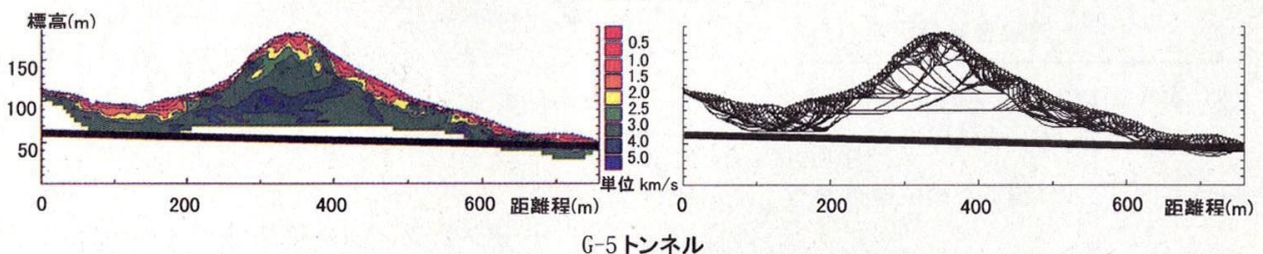

図-5 花崗岩におけるトモグラフィ法解析結果例(左 : 速度分布図, 右 : 波線図)

断する資料となる．図-4は，トモグラフィ法あるい は従来法による解析に供した走時図であり, トモグ ラフィ法で求められた速度分布に対する計算走時も 併せて示してある．測定走時と計算走時を比較する と，両者は概ね一致しているとみなせるが，最大 $5 \mathrm{~ms}$ 程度の差が見られる結果もある. 理想的には, 現場測定における走時と計算走時は一致しなければ ならないが, 実際には, 測定誤差, 2 次元モデル化 の問題, 数值解析上の誤差などにより両者は図に示 したように必ずしも一致しない: 一方, 従来法にお いても, 解析された速度構造に対して代表的な測点 における走時を計算し, 解析結果の妥当性を確認す ることが行われる。しかし，全ての測点について走 時を計算し, 速度構造の妥当性を確認することは, 一般的には行われていない。

図-5は，代表的な事例についてトモグラフィ法に
よる解析結果を示したものである、トンネル計画面 に波線が通過した解析結果が得られたのは表-3に示 すように，G-1，G-2(図-5)，G-3などのトンネルで あり，G-4，G-5(図-5)などのトンネルについては 坑口付近の土被りが浅い部分のみ波線が通過する結 果となっている.

図-6はトンネル計画面に波線が通過した代表的な トンネルについて，トンネルに沿った速度分布を示 したものである. 従来法とトモグラフィ法の速度分 布を比較すると，花崗岩および粘板岩のトンネルで は, 従来法が概称高い速度分布を示しており, 砂 岩・頁岩では，両者の速度分布は概ね等しい結果と なっている.この点については，4(2)にて詳しく検 討する.

Sh-1トンネル(結晶片岩)について, 施工時に切羽 観察が行われた位置における弾性波速度から切羽強 

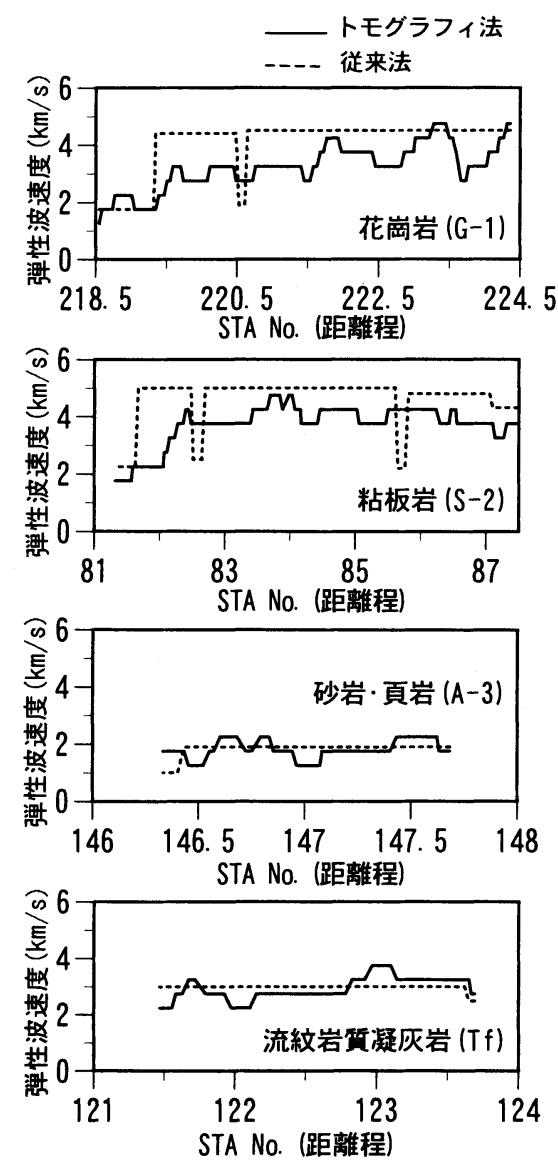

図-6 トンネルに沿った速度分布

度指数を推定し, 切羽観察記録の切羽強度指数と比 較した例を図-7に示す．図-7 (a) はトンネル中心に おける弾性波速度の分布を示したものであり, 図一 7 (b) はトモグラフィ法, 図-7 (c) は従来法における 切羽強度指数の変化を示したものである. トンネル に沿った速度分布を比較すると, 従来法では大部分 で速度が $5.2 \mathrm{~km} / \mathrm{s}$ であるのに対して，トモグラフィ 法では概ね3〜 $5 \mathrm{~km} / \mathrm{s}$ の範囲で変化する結果となって いる. 図-7 (b) (c) において, 破線部で示された推定 值 (最大) と推定值 (最小) に挟まれる区間が弾性波速 度から推定された切羽強度指数となり, 実線は切羽 観察記録の切羽強度指数を示している. 前述したよ うに, 実線が両推定値間 (最大と最小)に挟まれてい るとき, 弾性波速度から推定した切羽の状態と実際 が一致したと判定される. 従来法とトモグラフィ法 を比較すると, 従来法では弾性波速度分布の変化に 対応して切羽強度指数の変化は少ないが，トモグラ フィ法では複雑に変化する結果となっている，実際 の切羽強度指数はトンネルに沿って変化しており,
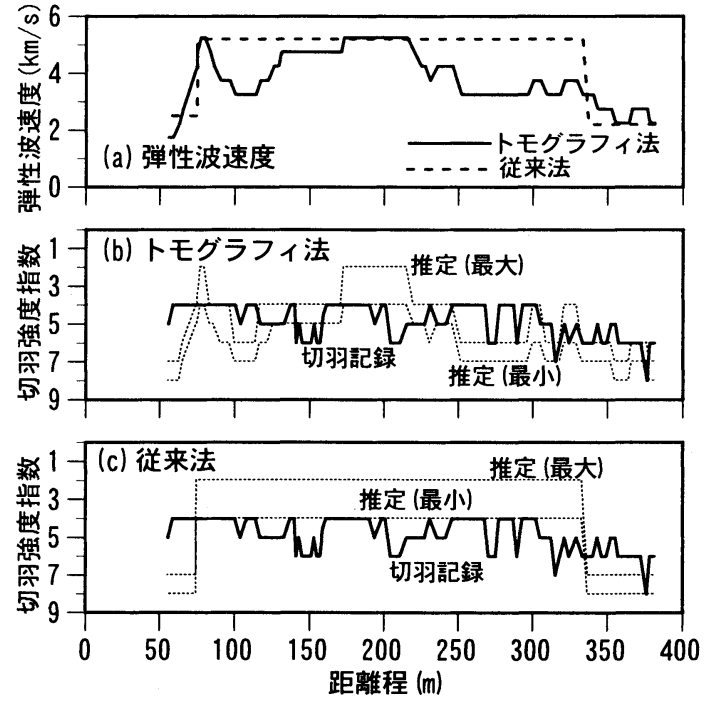

図-7 弾性波速度と切羽強度指数の分布 (Sh-1 トンネ ル)

トモグラフィ法における切羽強度指数と比較的調和 しているとみなせる. なお，このトンネルにおける 切羽強度指数一致率は, トモグラフィ法で $59 \%$, 従 来法で44\%である.

図-7に示したグラフを各トンネルについて作成し， トモグラフィ法の評価を行っている. また，各トン ネルにおける切羽強度指数一致率を計算した結果は, 表-3にまとめてある.

\section{（2）トモグラフィ法と従来法の速度分布の比較}

トモグラフィ法の解析結果において波線通過率が $100 \%$ となったトンネルについて, トンネル計画面 での速度分布の比較を行った結果を示す．図-8は, 花崗岩, 粘板岩, 砂岩·頁岩のトンネルについて, 切羽観察が行われた位置における従来法とトモグラ フィ法の速度值とプロットしたもである. 図におい て，プロットの面積が大きいほど頻度が高いことを 示しており, 例えば, 図-8 (a) 花崗岩では最も大き いプロットの頻度は, データ総数の約 $13 \%$ である. トモグラフィ法と従来法で求められた速度には相関 があるが, 花崗岩 (図-8 (a)) では, 速度 $2 \sim 3 \mathrm{~km} / \mathrm{s}$ で はトモグラフィ法が従来法に比較して高い速度を示 し, 速度 $4 \mathrm{~km} / \mathrm{s}$ 以上ではトモグラフィ法が従来法に 比較して低い速度を示す傾向が認められる. 波線通

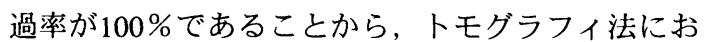
ける速度値は, 測定結果を反映した值であると考え られる. 粘板岩 (図-8 (b)) では, 速度 $1 \sim 3 \mathrm{~km} / \mathrm{s}$ で, 両者の速度は概ね等しいが， $3 \mathrm{~km} / \mathrm{s}$ 以上ではトモグ ラフィ法の速度が従来法に比較して低い傾向がある. 

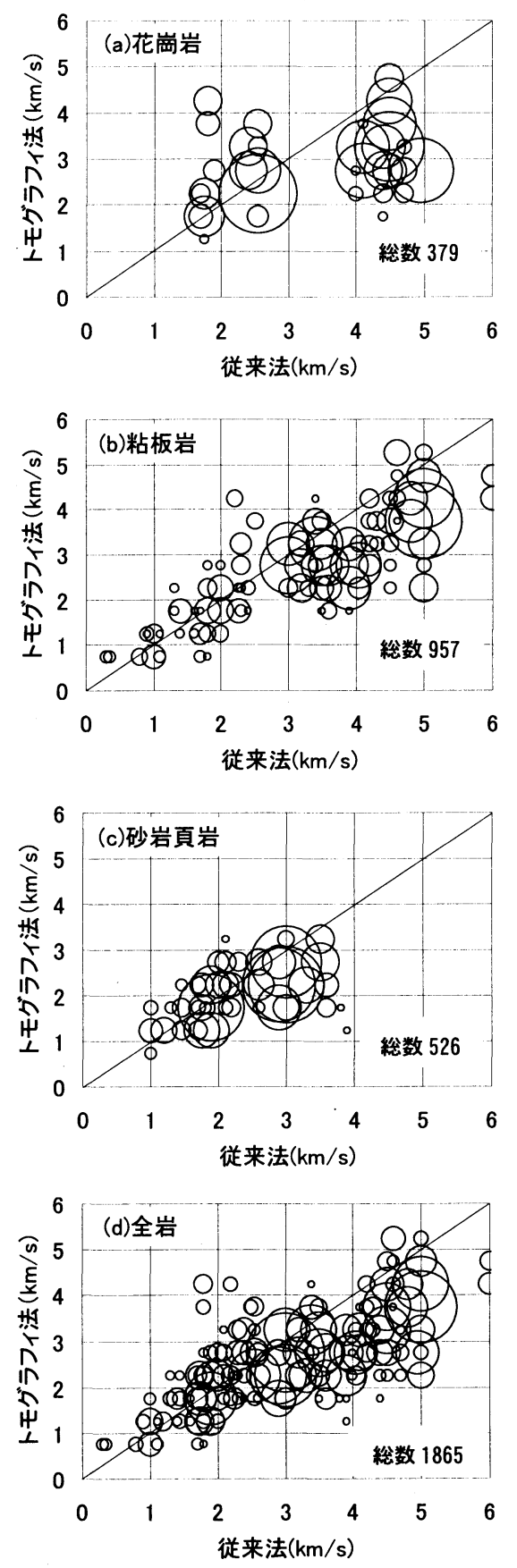

図-8 トモグラフィ法と従来法の弾性波速度の比較

砂岩·頁岩 (図-8 (c)) では，両者の速度は概ね等しい. 全岩 (図-8 (d)) では, 速度 $3 \mathrm{~km} / \mathrm{s}$ 以下では, 従来法と トモグラフィ法は概ね等しい解析結果となっている が， $3 \mathrm{~km} / \mathrm{s}$ 以上ではトモグラフィ法が従来法に比較 して低い速度を示す傾向がある. なお，トモグラフ イ法における速度は，初期値の与え方による影響を
受けている可能性があるが，その信頼性については 後ほど考察する.

図-9は, 花南岩, 粘板岩, 砂岩·頁岩のトンネル について, 従来法およびトモグラフィ法の速度の頻 度分布を示したものである. トモグラフィ法の頻度 分布では, ピークが一つであるのに対して, 従来法 では複数のピークを有している. 花崗岩 (図-9(a)) では, トモグラフィ法が3.0〜 3.5 km/s 最頻点とし た正規分布に近い分布を示すのに対して，従来法で は2.0〜 $2.5 \mathrm{~km} / \mathrm{s}, \quad 3.0 \sim 3.5 \mathrm{~km} / \mathrm{s}$ および $4.5 \sim 5.0 \mathrm{~km} / \mathrm{s}$ に ピークを有しており，4.5 $5.0 \mathrm{~km} / \mathrm{s}$ で最も頻度が高 く, 最頻点となるピークは, 従来法における基盤速 度に対応しているものと判断される．同様の傾向は 粘板岩, 砂岩·頁岩についても認められる. しかし, 砂岩·頁岩では, 花崗岩や粘板岩に比較して, 両手 法の最頻点における速度差は小さい.

従来法では, 解析結果は3〜 5層の速度層に区分さ れた離散的な速度分布となる．従来法で解析された 速度值が各トンネルで近い值となる場合, 図-9に示 すように, 複数のピークに分離した分布となると考 えられる. 一方, トモグラフィ法では連続的に変化 する速度分布として解析されることから，単一ピー クの頻度分布になったと推定される.

\section{（3）切羽強度指数によるトモグラフィ法の信頼性の 検討}

図-10 は, 各トンネルについて切羽強度指数一致 率を比較したものであり, 図-11 は花崗岩, 粘板岩, 砂岩・頁岩について切羽観察記録と弾性波速度から 推定した切羽強度指数のランク差を示したものであ る. 切羽強度指数一致率はトンネルにより異なるが, 多くの場合, 従来法に比較してトモグラフィ法は高 い一致率を示す. 全トンネルでみると, 従来法の一 致率は $56 \%$ であり, トモグラフィ法では $69 \%$ であ る. 切羽強度指数のランク差は, 图-11 に示すよう に, トモグラフィ法も従来法もランク差 0 に頻度が 集中し, ばらつきも概ね 1 の 範囲に納まっている. 以下, 岩種, 土被り厚および速度に関して, 切羽強 度指数一致率の検討を行う.

\section{a) 岩種}

花岡岩全体では, トモグラフィ法の切羽強度指数 一致率は58\%であり, 従来法では44\%となり, トモ グラフィ法が $14 \%$ 高い一致率を示す. 切羽観察記録 とのランク差は, 両手法ともランク差0に最頻点を もつ分布であるが, トモグラフィ法ではランク差-2 に, 従来法ではランク差-3にもピークを持つ結果と なっている. また, 最頻点のピーク形状に着目する 


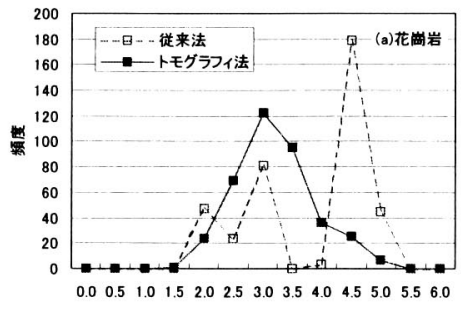

速度区分 $(\mathrm{km} / \mathrm{s})$

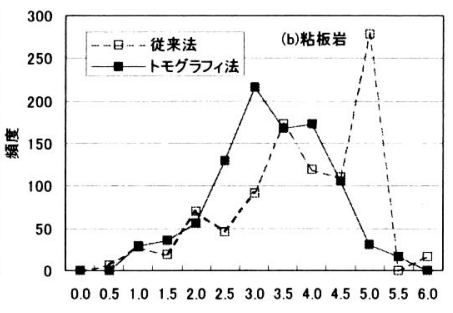

速度区分 $(\mathrm{km} / \mathrm{s})$

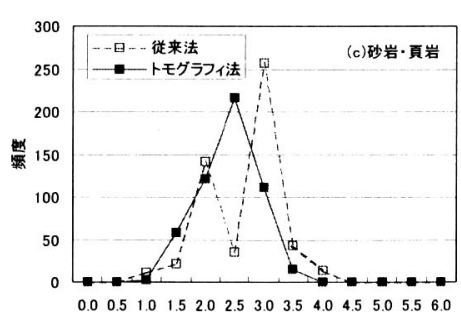

速度区分 $(\mathrm{km} / \mathrm{s})$

図-9 代表的な岩種における弾性波速度の頻度分布
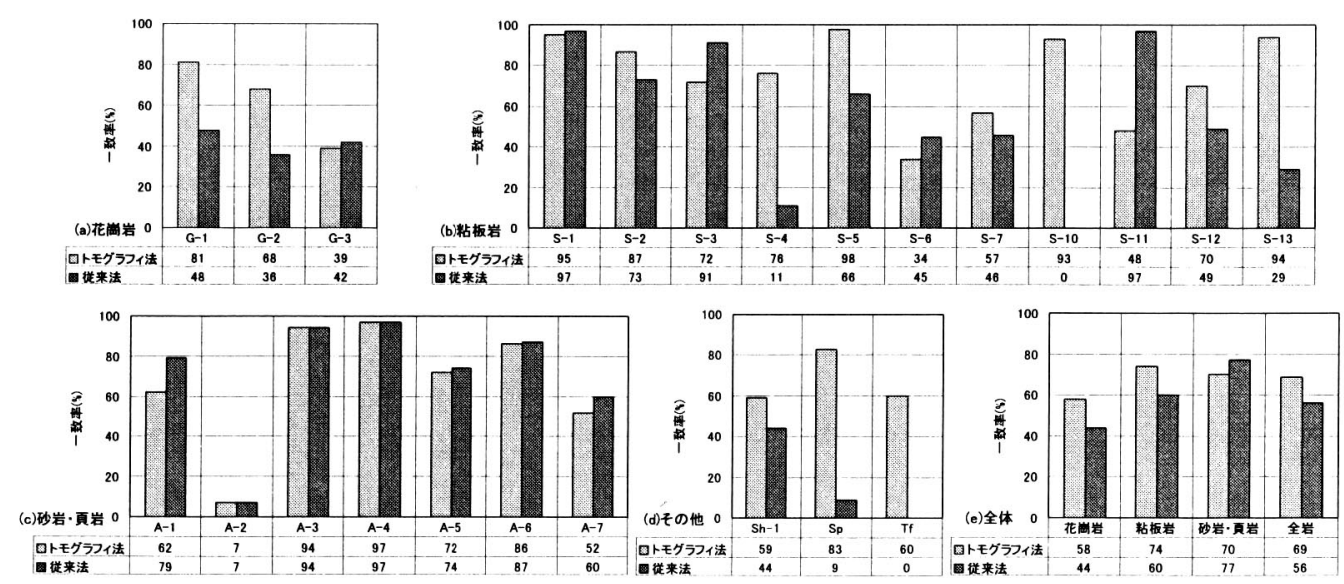

図-10 切羽強度指数一致率の比較

と，トモグラフィ法はランク差0を中心に正負に大 きな偏りがない分布であるが, 従来法では正側に偏 りのある分布となっている. このことは, 従来法で は弾性波速度から想定された地山状態より, 実際の 地山状態が悪くなる傾向があることを示している.

粘板岩全体では, トモグラフィ法の切羽強度指数 一致率は74\%であり, 従来法は60\%となり, トモグ ラフィ法が14\%高い一致率を示す. 切羽観察記録々 のランク差は, 両手法とも概ね \pm 1 ランク差に収ま る分布である. 分布形状に着目すると, 花崗岩と同 様, 従来法では正側に偏りのある分布となっている. S-11トンネルでは, 従来法で97\%と高い一致率であ るのに対して, トモグラフィ法では $48 \%$ と低い一致 率となっている，逆にS-10トンネルでは，トモグラ フィ法が93\%と高い一致率であるのに対して, 従来 法ではまったく一致していない.しかし, 両トンネ ルとも \pm 1 のランク差を許容すると, 両手法とも高 い一致率となり, 微妙な評価差によりこれらの極端 な結果が得られたものと考えられる.

砂岩·頁岩では, トモグラフィ法と従来法の切羽 強度指数一致率は前の2岩種と比べて近く, トモグ ラフィ法では70\%，従来法では77\%である。 また,
花崗岩, 粘板岩と比較して高い一致率を示す，両手 法とも一致率の低いA-2トンネルは， \pm 1 のランク差 を許容すれば, ともに $90 \%$ 以上の高い一致率となる. 一方, 切羽観察記録とのランク差については, 両手 法とも概ね \pm 1 ランク差に収まる分布となっており， 両手法の分布形状はほぼ一致している. 分布形状は 花南岩, 粘板岩と異なり, 負側に偏りのある分布と なっている. すなわち, 両手法の弾性波速度から想 定された地山状態より, 実際の地山状態が良好であ ったことを示している.

その他の岩種については, 結晶片岩 (Sh -1トンネ ル)では, トモグラフィ法における切羽強度指数一 致率は59\%であり, 従来法では44\%である. 蛇紋岩 (Spトンネル)では, トモグラフィ法では83\%, 従来 法では9\%であり, 流紋岩質凝灰岩 (Tfトンネル) で は, トモグラフィ法では $60 \%$, 従来法では0\%であ る. いずれのトンネルにおいても, トモグラフィ法 が高い一致率となっているが, 検討トンネルが1事 例であることから, 岩種としての傾向を示している かは明らかでない。

\section{b) 土被り厚}

図-12は, 土被り厚に対する切羽強度指数一致率 

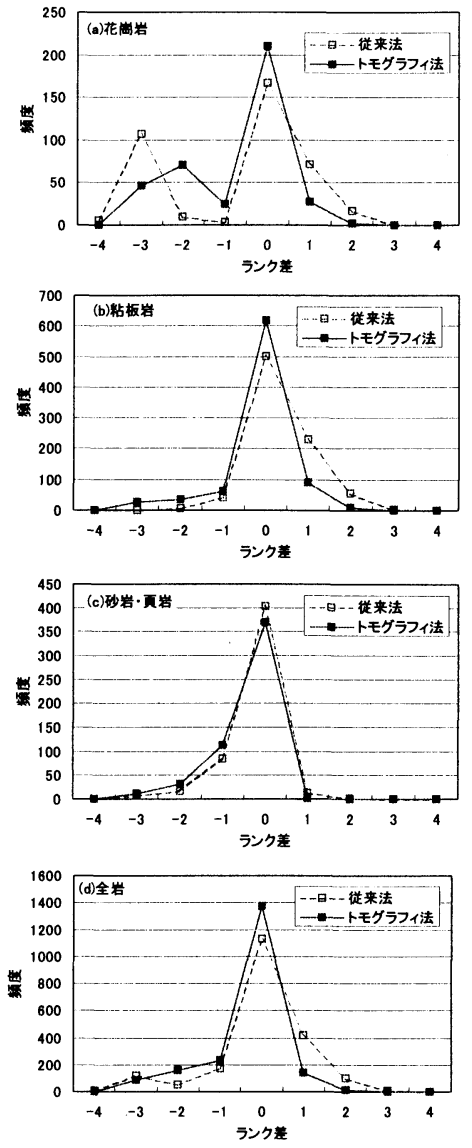

図-11 切羽観察記録と弾性波速度から推定された切羽 強度指数のランク差頻度分布

の変化を整理したものである. 花崗岩では, 土被り 厚30〜40mにおいてトモグラフィ法の一致率が従来 法より低いが, 他の土被り厚では高い結果を示す.

また, トモグラフィ法では, 従来法に比較して, 土 被り厚に対する一致率の変化が少ない。粘板岩では, 土被り厚60〜80mにおいて，トモグラフィ法の一致 率が従来法よりやや低い結果となっているが，他の 土被り厚では高い一致率である. 従来法では, 土被 り厚が薄い部分で一致率が低下するが，トモグラフ イ法では, 土被り厚に対して一致率は大きな変化は しない，砂岩·頁岩では，土被り厚30〜 50mでトモ グラフィ法の一致率が低いが, 全体的にみれば両者 の一致率に差はないものと考えられる．全岩種でみ れば, ほとんどの土被り厚において, トモグラフィ 法は従来法より高い一致率を示す.

花崗岩では, 粘板岩や砂岩·頁岩に比較すると, 特に従来法において土被り厚に対する切羽強度指数 一致率がばらつく結果となっている．これは, 花崗 岩における風化帯の厚さがトンネルごとに変化する
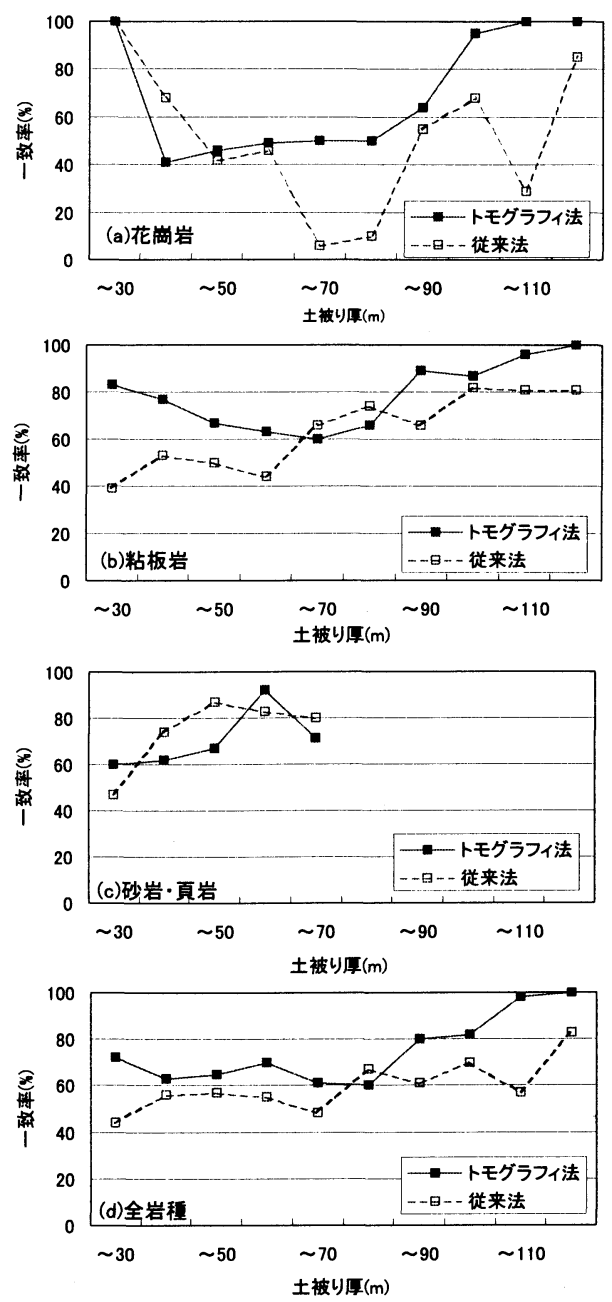

図-12 土被り厚と切羽強度指数一致率の関倸

ことと関係があると推定される.

\section{c) 速度値}

図-13は, 弾性波速度に対する切羽強度指数一致 率の変化を示したものである. 花崗岩ではいずれの 速度に対してもトモグラフィ法が高い一致率を示す. なお，従来法において速度 $3.0 \sim 4.0 \mathrm{~km} / \mathrm{s}$ における一 致率が低いのは，図-9に示したように，同速度にお ける頻度が低いことによるものと考えられる．粘板 岩では, 速度 $5.0 \mathrm{~km} / \mathrm{s}$ 以上で, トモグラフィ法の一 致率が従来法より低いが, 速度 $5.0 \mathrm{~km} / \mathrm{s}$ 以下では, 従来法より高い一致率を示す．砂岩·頁岩では, 速 度2.0〜3.0km/sにおいて従来法がトモグラフィ法よ り高い一致率を示すが, 速度 $3.0 \mathrm{~km} / \mathrm{s}$ 以上ではトモ グラフィ法が高い一致率を示す，全岩種では，いず れの速度においてもトモグラフィ法は従来法に比較 して等しいか高い一致率を示す. 

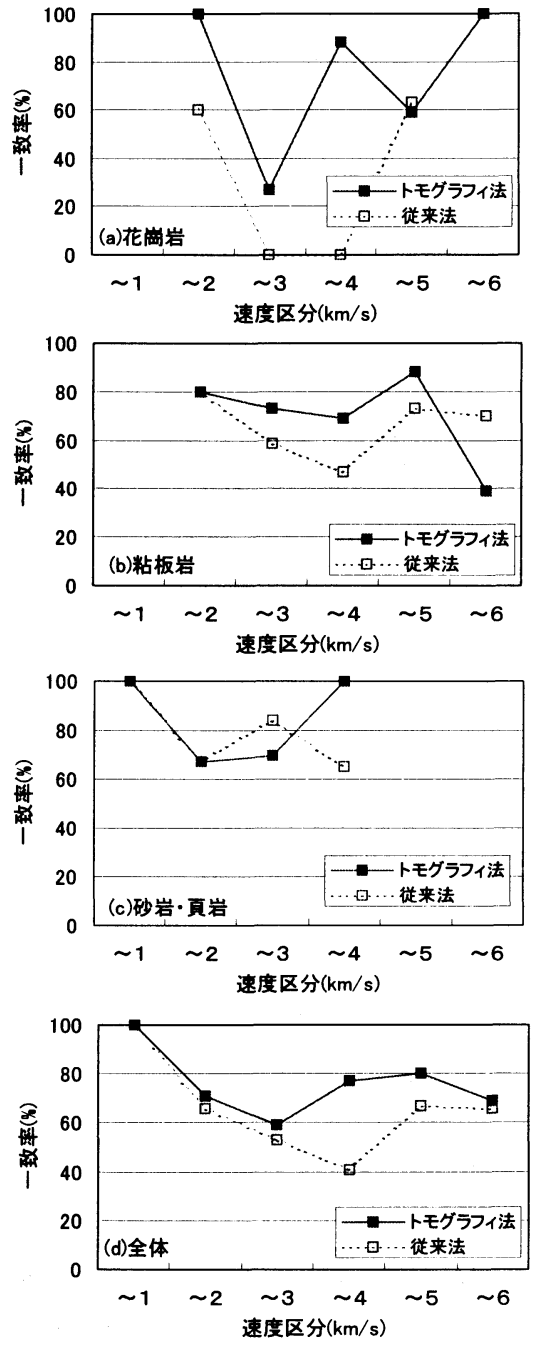

図-13 弾性波速度と切羽強度指数一致率の関係

\section{5.トモグラフィ法の適用性に関する考察}

\section{（1）切羽強度指数一致率による評価}

図-14は, トモグラフィ法と従来法の切羽強度指 数一致率を再整理したものである. ばらつきはある が, 多くのトンネルにおいて, トモグラフィ法が従 来法に比較して等しいか高い一致率を示している. また, トモグラフィ法では, 多くのトンネルにおい て50\%以上の一致率となっている. 一方, 従来法で は, 低い一致率から高い一致率まで分散した分布と なっている. なお図中において, 従来法トモグラフ イ法とも低い一致率となっているのはA-2トンネル の結果であり, 切羽強度指数において1ランクの誤 差を許容すれば, 90\%以上の高い一致率となる. 図 -12および図-13で示したように，トモグラフィ法の

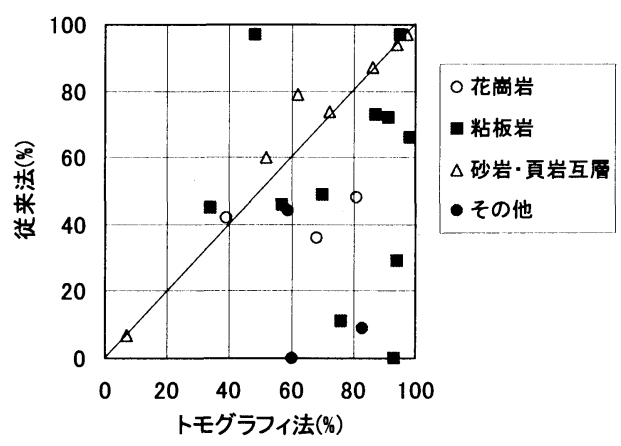

図-14 切羽強度指数一致率の比較

一致率は, 特定の速度や土被り厚において従来法よ り極端に低くなることはない．このことから，トモ グラフィ法は, 従来法と同等以上に地山状態を推定 することが可能であると判断される.

弾性波速度に着目すると, 図-8で示したように, 速度 $3.0 \mathrm{~km} / \mathrm{s}$ 以下ではトモグラフィ法と従来法の速 度はほぼ等しいが, 速度 $3.0 \mathrm{~km} / \mathrm{s}$ 以上ではトモグラ フィ法の速度が従来法に比較して低い值となる傾向 がある. この現象は, 切羽強度指数一致率にも反映 されていると考えられる. 砂岩·頁岩では, 従来法 とトモグラフィ法の一致率に顕著な差がみられない が, 花崗岩および粘板岩では一致率にばらつきが見 られ, 速度3.0 5.0km/sでは従来法の一致率はトモ グラフィ法に比較して低い值となっている (図-13). また, 花崗岩, 粘板岩では, 図-11に示した切羽観 察記録とのランク差の頻度分布において, 従来法の 頻度分布がやや正側に偏った分布となっている.こ のことは, 弾性波速度から推定した状態より実際の 地山状態が不良であることを意味しており, 従来法 における弾性波速度が高めの值であったと判断する ことができる. また，トンネルにおいて事前調査段 階にBなど良好な地山と地山分類された割合が，施 工時には低下している例がある11.5)。この場合，実 際の地山状況は, 弾性波探査 (従来法) より当初推定 された地山状態より不良であったことを示唆してい る. このようなことからも, 従来法の速度は, 地山 分類が $\mathrm{B}$ となるような速度の高い部分で, 高めの速 度となることが推定される。

\section{（2）波線の通過に関する考察}

図-15は，検討対象としたトンネルについて最大 土被り厚と測線長の関係を示したものでる. トモグ ラフィ法で波線がトンネル計画面を完全に通過した 結果は, 塗りつぶしたプロットで示してある.この 図から，概ね，土被り厚が $100 \mathrm{~m}$ 以上になると，波 線の通過が期待できない．また，表-3で示したよう 


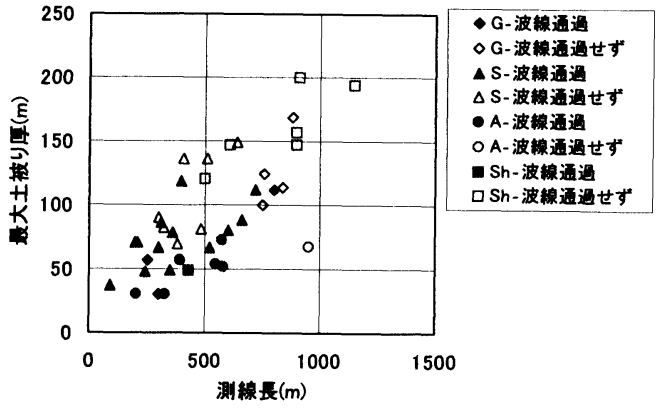

図-15 土被り厚と波線通過状況

に, 一つのトンネルについて, 測線が2ないし3測線 に分割されて測定されている場合, トンネル計画面 における波線の通過状況が悪くなっている. 従来法 では，基盤速度層が確認できれば，波線は必ずしも トンネル基面を通過する必要なく, トンネル基面に おける弾性波速度は基盤速度首の速度となる. しか し，表-3および図-10に示したように，従来法の切 羽強度指数一致率は, トモグラフィ法における波線 通過率にかかわらずばらついた結果となっている.

また, 図一7に示したように, 切羽の状態 (切羽強度 指数) は必ずしも一様ではなく変化している。これ らのことは, 従来法で基盤速度層が十分に把握でき ていないと考えられ，土被りの厚い部分で従来法の 解析精度が悪くなっていると推定される. 一方, 図 -2および図-3を比較すると, 表層部では従来法と卜 モグラフィ法で速度に大きな差は見られない。トモ グラフィ法の結果によれば, この部分は密に波線が 通過する所となっている. したがって, 従来法にお いてもトンネル計画面において十分に波線が通過す るように測点配置を工夫することが重要であり, 遠 隔起振などを有効に活用することが望ましい. しか し, 用地など実務上の問題として必ずしも遠隔起振 を実施することが可能ではない，一方，トモグラフ イ法では, トンネル計画面に波線が通過した場合,

図-14に示したように概ね $50 \%$ 以上の切羽強度指数 一致率が期待できる．また，ボーリング孔に起振点 や受振点を設置することで, トンネル計画面に波線 が通過するように工夫することが可能であり，トモ グラフィ法を用いることで，より正確に地山状況が 推定できるものと考えられる.

\section{6. 今後の課題とまとめ}

検討を行ったトンネルの地質は, 主に花崗岩, 粘 板岩および砂岩・頁岩であった．結晶片岩について
は, 検討トンネル数が少なくトモグラフィ法の適用 性の評価に至っていない. また, 新第三紀堆積岩類, 火山砕屑岩類, 火山岩類も山岳トンネルにおける代 表的な地質である.これらの岩種に対しても，トモ グラフィ法の適用性を検証する必要がある。一方, 弾性波探査において低速度帯を検出することは重要 である.このためトモグラフィ法と従来法を併用し て，その位置を予測することが良いと考えれる。

今回対象としたトンネルにおいては，ボーリング 孔やトンネル切羽における起振や受振を用いた測定 は実施されていない. トモグラフィ法においてボー リング孔を用いた測定を行うことで, トンネル計画 面での地山評価の精度の向上が期待でき，これを検 証することも重要である.

一方, トモグラフィ法における解析は従来法に比 較して非常に高速である. マイクロコンピュータで 解析することが可能であることから，現場において 解析を実施し，その場で評価を行うことも無理では ない．波線が通過しなかった個所をその場で検出す ることが可能であり, 最適な測点配置で再計測を行 うことが可能となる. また, このようにして測定さ れた走時データを用いることで, 従来法においても より良い解析結果が得られることが期待できる.こ のためには, 弾性波探查装置で得られた測定波形か ら迅速に初動を読み取り, 解析のためのデータファ イルを自動的に作成するシステムが必要となる.

近年, トンネル調査において, トモグラフィ法が 用いられるようになってきた. トモグラフィ法のト ンネル調查における適用性について, 本研究から得 られた知見を要約すると以下のとおりとなる.

(1)中川ら ${ }^{5)}$ が提案した切羽強度指数一致率につい て, トモグラフィ法と従来法を比較した結果, 砂岩·頁岩では同程度, その他の岩種ではトモ グラフィ法が11〜 14\%高い一致率となった.

(2)土被り厚および弾性波速度值に対する切羽強度 指数一致率の変化を検討した結果, トモグラ フィ法では, 特定の土被り厚や速度で一致率 が極端に悪化することはない.

(3)11および(2)から，トモグラフィ法はトンネル調 査に適用性があると判断され, トンネル地山 評価においてトモグラフィ法は有効な手法で あるといえる．また，トモグラフィ法で得ら れた速度分布を用いて設計することにより， より合理的な設計となることが期待できる.

(4)検討対象としたトンネルにおいて, トモグラフ イ法と従来法の弾性波速度を比較した結果, 速度 $3.0 \mathrm{~km} / \mathrm{s}$ 以下では両者の值は概ね等しいが, 
$3.0 \mathrm{~km} / \mathrm{s}$ 以上ではトモグラフィ法が低めの速度 となる傾向がある.

(5)切羽強度指数一致率の観点から考察すると, 花 岡岩, 粘板岩において従来法で解析された基 盤速度は, 高めの速度として解析されている 可能性がある.

本研究において, トモグラフィ法の解析を実施し たのは弾性波探査未経験者である.このことから, トモグラフィ法では, 調査技術者の経験や技術によ らず地盤の弾性波速度を解析することができると考 えらる. トモグラフィ法は, 若手技術者が大きな誤 りを犯すことなく弾性波探査結果を解析でき, 従来 法の解析をより適切な結果とするための一手段とな りうるものと考えられる. また, 本研究で用いた弾 性波探査測定結果は, 従来法解析を前提としたもの であった. トモグラフィ法解析結果をより精度の高 いものとするためには, ボーリング孔などを利用し た測定が望ましい。この場合, 弾性波探査における 調査費は若干増加するが, トンネル構築全体に対し ての合理化に寄与するものと考えられる.

謝辞：日本道路公団各工事事務所および山口県土木 建築部からは, トンネルの調査施工に関する貴重な データの提供を受けるとともに公表することを許さ れた. 本研究は, これらのデー夕に基づくもであり, データの提供を頂いた各機関には深く感謝の意を表 します，岩本啓幸氏 (元山口大学学生)には, データ 整理にご協力を頂くとともに多くの議論を頂いた. また, 保岡哲治氏 ( (株) 大林組)には, 貴重なご意見 を頂いた。ここに記して感謝の意を表します。

\section{参考文献}

1) 鈴木昌次, 古川浩平, 井上洋司, 中川浩二 : NATM施 工実績に基づく事前設計の評価に関する一考察, 土木
学会論文集, No.427/VI-14, pp. 261-270, 1991 .

2）萩原尊礼：基盤面の傾斜が一様でない場合の走時曲線 解析法, 地震, Vol.10, No.11, pp. 463-468, 1938.

3) 田冶米鏡二, 武内俊昭 : 屈折法の解析に対する萩原の 方法の拡張, 物理探鉱, No.11, pp. 44-46, 1958.

4）林宏一, 斎藤秀樹: 高精度屈折法地震探査の開発と適 用例, 物理探査, No.51, pp. 471-492, 1998.

5）中川浩二, 保岡哲治, 北村晴夫, 三木茂, 藤本睦, 木 村恒雄 : トンネル事前設計における地質調查の問題点 とその評価に関する研究, 土木学会論文集, No.658/VI-48, pp. 34-43, 2000.

6) 例えば, 鈴木守, 富田宏夫：トンネル地質調查の性格 と問題点(2), トンネルと地下, 第 24 , 巻 10 号, pp.49$59,1993$.

7) 松岡俊文, 江坂照也 : レシプロカルプリンシプルに基 づくレイトレーシングについて, 物理探査学会第81回 学術講演会論文集, pp. 107-112, 1989.

8) Vidal, J.: Finite-difference calculation of travel times, Bulletin of the Seismological Society of America, Vol.78, No6, pp. 2062-2076, 1998.

9) Qin, F., Luo, Y., Olsen, K.B., Cai, W. and Schuster, G.T.: Finite-difference solution of the eikonal equation along expanding wavefronts, GEOPHYSICS, Vol.57, No.3, pp. 478-487, 1992.

10) 三木茂, 井上浩一, 徳外幸隆, 中川浩二 : トモグラフ 々的弾性波探查解析法における初期值設定について, 第53回平成13年度土木学会中国支部研究発表会発表概 要集, pp.319-320, 2001.

11) 日本道路公団：設計要領第三集第 9 編トンネル, pp. 33-36, 1985.

12）日本鉄道建設公団：NATM設計施工指針， 1996.

13）基礎地盤コンサルタンツ株式会社 : 高密度弾性波探查 解析プログラムパンフレット, 1999.

(2001. 7. 23 受付)

\title{
A STUDY ON THE EVALUATION OF IN-SITU ROCK CONDITIONS BY THE TOMOGRAPHIC METHOD IN TUNNEL GEOLOGICAL INVESTIGATIONS
}

\author{
Shigeru MIKI, Yukinobu YOSHIDA, Koichi INOUE and Koji NAKAGAWA
}

\begin{abstract}
We have introduced the tomographic method to the seismic exploration in tunnel investigations, and have presented a way to evaluate the performances of the tomographic method based on geological observations. Geological observation records at the face have been utilized to measure the performances of the tomographic method and the reciprocal method. And these seismic methods have been examined in 35 tunnel sites. The performances of the tomographic method varied with tunnel sites. However, the tomographic method showed same or good performances compared with the reciprocal method in many tunnel sites. This leads to the conclusion that the tomographic method as well as the reciprocal method can be applied in tunnel investigations.
\end{abstract}

